\title{
PANCASILA DALAM KEHIDUPAN MUSLIM DI LINGKUNGAN MASJID AL MANAR MENDUNGAN
}

\author{
Siti Shofiyatun \\ Institut Islam Mamba'ul 'Ulum (IIM) Surakarta \\ Shof_fiiya@yahoo.com
}

\begin{abstract}
Pancasila is a guide for the Indonesian people in society, nation and state. Over time, the ideology of the Pancasila began to fade in people's lives; this could be due to the current of globalization. The community began not to pay too much attention to the values in the Pancasila. As one example this can be seen around the Al-Manar mosque which tends to individualism. The existing Pancasila values seem to be marginalized and become a new problem today. Itmakes writer to examine how the people understand the Pancasila in the Al-Manar mosque and how to plant the values of Pancasila and religious teachings in Muslim life in the Al-Manar mosque The purpose of this paper is to be able to provide insight to the community on the importance of planting Pancasila values and teachings. The method used in this study is qualitative descriptive. Data is collected through observation, interviews and documents related to research. The technique used in analyzing is spreading data, retrieving data according to the problem and drawing conclusions. From the results of the study it was found that the majority of the people in the Al-Manar mosque understood the meaning and function of the Pancasila as the state foundation and unifying the Indonesian nation. Pancasila values do not conflict with the values of Islamic teachings. The pattern of understanding of some Muslim communities in the Al-Manar mosque understands Pancasila as its own ideology, and the teachings of Islam as its own ideology.
\end{abstract}

Keywords: Pancasila, Muslim Life, Al-Manar Mosque.

\section{Pendahuluan}

Pancasila sebagai ideologi bangsa Indonesia memiliki nilai-nilai dasar yang terkandung di dalamnya secara riil berakar dan hidup dalam masyarakat atau bangsa Indonesia, karena nilai-nilai dasar tersebut bersumber dari budaya dan pengalaman sejarah dari bangsa Indonesia itu sendiri (Surip, 2016: 48). Sehingga Pancasila adalah jiwa bangsa Indonesia. Seiring perkembangan zaman dan derasnya arus globalisasi saat ini, setiap individu sering melupakan bahkan mempertanyakan nilai-nilai yang ada dalam Pancasila serta bagaimana pengamalan nilai-nilai Pancasila tersebut. Harus diakui bahwa pada masa lampau ada mutualmisunderstanding antara sebagai agama dan Pancasila sebagai 
ideologi. Kesalahpahaman itu lebih banyak pada berbagai kepentingan politik daripada substansinya; atau lebih dikarenakan oleh ketidakjelasan paradigma dan cara pandang (Kuntowijoyo, 1997: 79).

Menurut Abdul Hadi W.M., hubungan Pancasila dengan ajaran etika agamaagama yang ada di dunia melayu, khususnya sangatlah kental. Pepatah melayu "adat bersanding syarak, syarak bersandi kitabullah" (adat kebiasaan Melayu bersandar pada syariat dan syariat bersandar pada kitabullah) menyiratkan keselarasan Pancasila dengan, sila-sila Pancasila merupakan hasil penggalan dari budaya beragam etnik (Aceh, Mingkabau, Jawa, Sunda, Madura,bugis, Makasar, dan sebagainya) yang memeluk. Jadi 90\% masyarakat Indonesia beragama, sudah tentu mewarnai nilai-nilai moral bangsa, sehingga Pancasila sebagia moral bangsa Indonesia sangat terpengaruh oleh kebudayaan yang merupakan faktor yang dominan dalam kehidupan masyarakat (Karim, 2004: 39).

Soepomo menganjurkan Indonesia tidak menjadi negara, tetapi menjadi negara yang memakai dasar moral yang luhur yang dianjurkan juga oleh agama. Alasan Soepomo inilah yang menjadi argumen kesediaan kalangan nasionalis untuk menerima usulan penggantian “tujuh kata”(dengan kewajiban menjalankan syariat bagi pemeluknya (Kansi, 2005: 29). Sudah banyak tulisan yang mengulas bahwa sila-sila dalam Pancasila tidak satu pun yang bertentangan denganajaran agama. Sebaiknya, tidak satu pun ajaran yang bertentangan dengan Pancasila.

Berikut dapat kita lihat korelasi antara ajaran dengan nilai-nilai Pancasila: pertama, Ketuhanan Yang Maha Esa selaras dengan Q.S Al-Ikhlas, Asy-Syura' (tentang hormat menghormati pemeluk agama lain), Q.S Al-Kafirun (saling menghormati ibadah agama lain), Al-Baqarah: 256 (tidak memaksakan kehendak dan agama kepada pemeluk agama lain). Kedua, Kemanusiaan yang adil dan beradab selaras dengan Q.S Al-Isra': 70 (manusia diakuai dan diperlukan sesuai dengan harkat dan martabatnya sebagai makhluk Tuhan), Al-Hujurat: 13 (manusia mempunyai kesamaan derajat hak dan kewajiban tanpa perbedaan suku, agama, turunan, kepercayaan, jenis kelamin kedudukan sosial dan warna kulit), Al- Maidah: 8 (mengembangkan sikap saling mencintai sesama manusia, tenggang rasa tepo seliro dan tidak semena-mena terhadap orang lain), An-Nisa': 135 
(menjunjung tinggi nilai-nilai kemanusiaan, gemar membela kebenaran dan keadilan), Al-Baqarah: 213 (merasa bagian umat manusia dan berkewajiban mengembangkan sikap hormat menghormati dan bekerjasama dengan bangsa lain) Ketiga, Persatuan Indonesia, senada dengan Q.S Ali-Imron: 103 (manusia Indonesia menempatkan peratuan, kesatuan, kepentingan dan keselamatan bangsa diatas kepentingan pribadi dan golongan). Keempat, Kerakyatan yang dipimpinoleh hikmat kebijaksanan dalam permusyawaratan perwakilan. Sesuai dengan Q.SAlAn'am: 132 (warga masyarakat mempunyai kedudukan, hak dan keajiban yang sama), Asy-Syura': 38 (tidak boleh ada suatu kehendak yang dipaksakan kepada pihak lain). Ali-Imran: 159 (keputusan yang menyangkut kepentingan bersama terlebih dahulu diadakan musyawarah. Kelima, Keadilan sosial bagi seluruhrakyat Indonesia. Hal ini sesuai dengan Q.S Al-Baqarah: 177 (manusia Indonesia menanyadari hak dan kewajiban yang sama untuk menciptakan keadilan sosial dalam kehidupan masyarakat Indonesia. Mengembangkan perbuatan luhur mencerminkan sikap dan suasana kekeluargaan dan kegotongroyongan). An-Nahl: 90 (bersikap adil terhadap sesama, menjaga keseimbangan antara hak dan kewajiban serta menghornati hak-hak orang lain).

Kondisi masyarakat di sekitar lingkungan masjid Al-Manar cenderung individualisme. Nilai-nilai Pancasila yang ada seakan sedikit dikesampingkan dan menjadi permasalahan baru dewasa ini. Disekitar masjid Al-Manar pada umumnya terbagi menjadi empat kelompok masyarakat dalam memahami dan memandangPancasila yaitu pertama orang yang anti Pancasila, kedua orang yang sekuler dan mengagungkan Pancasila sebagai ideologi bangsa, ketiga adalah orang yang memandang bahwa dan Pancasila tidak ada keterkaitannya, dan keempat orang yang menganggap bahwa Pancasila adalah bagian dari nilai-nilai keindonesiaan.

Berdasarkan permasalahan di atas, maka penulis tertarik untuk meneliti lebih lanjut berkaitan dengan Pancasila dalam kehidupan Muslim di lLingkungan masjid Al-Manar Mendungan. Untuk mendapatkan data, peneliti melakukan wawancara, observasi dan mengumpulkan dokumenter terkait dengan penelitian. Dari data tersebut peneliti menganalisa dan memaparkan data yang telah diperoleh 
yang sesuai dengan permasalahan dalam penelitian. Dengan penelitian ini peneliti berharapan dapat memberikan wawasan kepada masyarakat terhadap pentingnya penanaman nilai-nilai Pancasila dan ajaran.

\section{Pembahasan}

\section{Gambaran Umum Masjid Al-Manar.}

Masjid Al-Manar merupakan masjid yang pertama kali didirikan di Mendungan Rt 20/Rw 04, Pabelan, Kartasura, Sukaharja. Sebelum berdirinya masjid Al-Manar, masyarakat desa Mendungan masih jauh dari, banyak yang melakukan kemaksiatan dan kesyirikan seperti melakuan persembahan kepada jin, membakar kemenyan, mabuk-mabukan dan banyak preman. Berawal dari kegiatan TPA anak-anak yang dipelopori oleh Ibu Siti Wahyuni salah seorang anak kos di rumah ibu Iskiyat yang pada mulanya mengajar putra-putra Ibu Iskiyat. Seiring berjalannya waktu TPA yang diikuti anak-anak mulai mendapat perhatian masyarakat sekitar dan murid-murid TPA semakin banyak. Ketertarikan para orang tua dalam belajar agama juga meningkat, mulailah selanjutnya diadakan pengajian ibu-ibu sekitar di rumah salah seorang warga.

Selain kegiatan masyarakat, masjid Al-Manar juga bekerjasama dengan AMCF (Asian Muslim Charity Foundation) mendirikan mahad tahfidz Al-Qur'an untuk putri. Yang berlokasi di lantai pertama sayap barat. Kegiatan pembelajaran tahfid dilaksanakan setiap kecuali hari Minggu dari pagi sampai siang. Semenjak didirikan masjid Al-Manar ini kondisi masyarakat sekitar masjid menjadi lebih baik. Tidak ada lagi yang melakukan kesyirikan seperti melakukan persembahan untuk jin, membakar kemenyan di rumah atau dikuburan, warga yang pemabuk sudah tidak ada lagi serta preman juga sudah tidak ada. Dan banyak pula masjid- masjid yang didirikan di sekitar mendungan. Warga masyarakan yang notabene baragama abangan sudah tercerahkan dengan dakwah masjid Al-Manar menjadi muslim yang hakiki. Kondisi masyarakat yang harmonis dengan mayoritas muslim serta kerukunan antar warga yang tetap terjaga baik antar sesama muslim maupun dengan selain muslim yang minoritas. 


\section{Pemahaman Pancasila: Arti, Fungsi, dan Penanaman Nilainya}

Bagi bangsa Indonesia kedudukan Pancasila sangat penting. Pancasila adalah dasar negara ini. Kelima silanya merupakan rumusan berpikir dan bersikap rakyat Indononesia. Pancasila adalah sebuah kata yang berasal dari bahasa Sansekerta yang berarti lima batu karang atau lima prinsip moral (Muhammad Yamin, 437). Pancasila adalah pandangan hidup, fundamental negara kebangsaan, dan kesatuan Republik Indonesia juga moral kesuluruhan moral yang berupa sikap, tingkah laku, dan perbuatan manusia Indonesia yang terangkum dalam kelima sila Pancasila: Ketuhanan Yang Maha Esa, kemanusaan yang adil dan beradab, Persatuan Indonesia, Kerakyatan yang dipimpin oleh hikmat kebijaksanaan dalam permusyawaratan perwakilan, dan Keadailan sosial bagi seluruh rakyat Indonesia (Adian Husaini, 50). Hal ini seperti yang diungkapkan Ustadz Furqon Hasbi:

Pancasila berasal dari kata panca yang berarti lima dan sila berarti sendi atau dasar. Pancasila merupakan dasar negara Indonesia terdiri dari lima sila sebagai kristalisasi kebudayaan bangsa Indonesia yang pluralis, berbedabeda suku, ras, agama dan bahasa tetapi tetap satu. Saya sudah lupa apa itu Pancasila, karena saya belajar Pancasila dulu ketika saya masih SD, saya melanjutkan sekolah di pondok Gontor yang tidak diajarkan Pancasila sama sekali, saya juga melanjutkan kuliah di bidang agama, jadi saya sekarang lebih fokus kepada dakwah. Jadi saya belajar Pancasila dari membaca.

Dari data diatas penulis dapat menyimpulkan bahwa Pancasila adalah dasar negara Indonesia yang berfungsi sebagai pemersatu Bangsa Indonesia yang beranekaragam budaya, ras, suku, agama, dan bahasa. Pancasila sebagai ideologi bangsa sudah mulai terlupakan dan sejarah atau historis Pancasila sudah mulai luntur. Umat terkesan memisahkan diri dari Pancasila. sebagai agama dan Pancasila sebagai ideologi yang berdiri sendiri. Senada dengan apa yang diaktakan Ibu Nuraini:

Pancasila adalah dasar negara, kami masih ingat kelima sila tersebut karena setiap pertemuan Ibu-ibu PKK kami selalu membacanya dan pertemuan ini dilaksanakan setiap sebulan sekali, jadi kami hapal Pancasila yang berisi lima butir mulai dari sila pertama hingga sila kelima, hanya saja kami tidak mendalami esensi dari nilai-nilai Pancasila tersebut.

Bagas Pamor mengungkapkan: 
Pancasila adalah dasar negara Indonesia atau cita-cita bangsa Indonesia. Sebagai dasar negara, Pancasila berfungsi untuk memepersatukan bangsa Indonesia.

Pertumbuhan Pancasila sebagai Ideologi kebangsaan mulai dengan cita- cita kebangsaan yang bermula pada kebangkitan nasional yang menjadi jelas dalam kongres pemuda tanggal 28 Oktober 1928. Namun posisi Pancasila sebagai Ideologi Kebangsaan itu mengalami perkembangan yang signifikan dan mendapat kemantapan dalam dekrit presiden sukarno pada tanggal 5 Juli 1959 yang mengesahkan pemberlakuan kembali Uud 1945. Terlebih lagi pada masa orde lama, Pancasila sebagai Ideolagi bangsa sangat kental sekali ketika masa rezim Soeharto yang mewajibkan setiap warganya untuk menghafal Pancasila dan merancanangkan pelatihan P4 (Pedoman Penghayatan dan Pengamalan Pancasila). Seakan-akan Pancasila sangat dianggungkan. Hal inilah yang membuat takut para cendekiawan muslim pengagungan tehadap Pancasila yang berlebihan dapat mengesampingkan ajaran. Sehingga pada masa reformasi ideologi Pancasila itu mulai luntur. Ustadz furqon:

Pada masa Pak Soeharto menjadi presiden Indonesia, pada saat itu, Pancasila diajibkan sebagai ideologi. Siapa yang menolak, berarti musuh negara, ditangkap, dipenjara sebagai orang subversif, dan lain-lain. Jadi pada waktu itu Pnacasila sagat melekat pada setiap orang. Setelah masa reformasi, sudah tidak seketat apada masa Soeharto, ideologi Pancasila sedikit demi sedikit mulai luntur.

Pancasila sebagai dasar negara atau ideologi negara sangatlah diperlukan karena Indonesia bukanlah negara. Perlunya sebuah negara untuk memiliki peraturan yang mengatur jalannnya pemerintahan sebagai dasar hukum dalam mengambil keputusan. Berbagai ras dan suku serta agama hidup bersatu padu di Indonesia. Para fouding fathers menginginkan sebuah dasar negara yang digali dari kebudayaan Indonesia yang akan menjadikan negara Indoneisa negara persatuan dan kesatuan. Sebagai mana dikakan oleh Yunus Prasetya:

Pancasila sebagai ideologi atau dasar negara sangatlah diperlukan, jika kita melihat Indonesia terdiri dari banyak pulau, tersebar luas dari penjuru sabang sampai merauke, bahasa kita sangat beraneka ragam, belum lagi suku-sukunya sangat banyak sekali, walupun mayoritas agama kita adalah 
tetapi juga ada penganut-penganut agama lainnya. Karena indonesia bukanlah negara, jadi menjadikan Panacasila sebagai dasar negara adalah pilihan yang tepat yang dilakukan oleh para pendiri negara ini untuk menjadikan negara kita bersatu tidak bercerai berai, buktinya sampai sekarang masyarakat Indonesia masih dapat mempertahankan kerukunannya. Dan hal ini akan lebih bagus lagi bila Umat menjalankan Pancasila sesuai dengan Al-Qur'an dan Hadist.

Senada dengan apa yang dikatakan Basuki Widodo:

Pancasila menurut saya adalah visi-misi atau cita-cita bangsa Indonesia untuk membentuk negara yang didasarkan dalam lima sila yang dirumuskan oleh bapak pendiri bangsa yang ingin Indonesia menjadi negara yang berketuhanan, menjadi negara yang adil dan beradab serta menjadi naegara yang makmur.

Umat di lingkungan masjdi Al-Manar sangat paham betul akan makna dan fungsi Pancasila bagi bangsa Indonesia selain sebagai dasar negara atau ideologi bangsa juga berfungsi sebagai pemersatu bangsa. Ada sebagian umat yang memahami Pancasila hanya sebagai ideologi tersendiri dan adalah ideologi tersendiri walaupun sila-sila Pancasila tidak bertentangan dengan ajaran. Hal ini seperti yang disampaikan Ibu Nuraini:

Sila-sila Pancasila itu tidak bertentangan dengan ajaran, dari sila1 sampai lima semua ada dalam ajaran, namun kami dalam kehidupan sehari-hari ya kami merasa kami menjalankan ajaran bukan menjalankan nilai-nilai Pancasila, begitu juga saya menanamkan kepada anak-anak saya tentang nilai-nilai ajaran bukan mengamalkan nilai-nilai Pancasila, contohnya mengesakan Allah ini ya ajaran mewajibkan umatnya untuk menyembah Allah saja.

Ada pula umat Muslim yang memahami Pancasila sebagai bagian dari ajaran. Sebagai agama dan Pancasila sebagai ideologi tidak pantut untuk dipertentangkan. Sila-sila Pacasila berkaitan erat dengan ayat-ayat Al-Quran. Seperti yang diungkapkan Yunus Prasetya kepada penulis:

Pancasila adalah bagian dari, rumusan Pancasila adalah hasil dari pemikiran orang-orang muslim, kalau kita melihat sejarah perumusan Pancasila maka kita akan mengetahui bahwa Pancasila itu berasal dari, Piagam Jakarta sebagai buktinya sebelum dihapuskan tujuh kata dan diganti dengan Ketuhanan Yang Maha Esa berisisikan Ketuhana, dengan kewajiban menjalankan syariat bagi pemeluk-pemeluknya. Sila ini adalah 
Tauhid didalam, agama-agama lain tidak ada yang mengesakan Tuhan selain.

Ada pula umat yang anti dengan Pancasila, mengganggap bahwa Pancasila adalah bukan dari. Hal ini seperti yang diungkapkan Yunus Prasetya:

Ada juga umat yang mengganggap bahwa Pancasila itu adalah thoghut atau produk thoghut buatan manusia jadi dengan dalil berhukum selain hokum adalah kafir. Hal ini sama dengan pandangan saya dulu ketika saya masih sekolah di pondok Ngruki. Kami didoktrin bahwa Pancasila adalah produk thoghut, bahkan ketika melihat polisi pun kami menganggap dia itu thoghut, setelah saya belajar diperkuliahan dan bertemu dengan salah seorang ustadz yang mengajari saya maka saya pun terbuka pikirannya, dan mengetahui hakekat Pancasila. Kesalahpahaman akan Pancasila ini dikarenakan sebagian Umat tidak mengetahui Pancasila secara historisnya. Alhamdulillah dalam jamaah kami menurut sepengetahuansaya tidak ada yang berpemahaman seperti itu.

Dalam penelitian ini jamaah masjid Al-Manar tidak ditemukan pola pemahaman yang menganggap Pancasila adalah thoghut dan pola pemahaman sekuler. Pola pemahaman Umat tentang Pancasila dapat kita kategorikan ke dalam empat kelompok yaitu pertama umat anti Pancasila, yang kedua umat yang memahami Pancasila sebagai dasar negara secara simbolis saja dan menganggap bahwa ideologi tersendiri dan Pancasila ideologi tersendiri walaupun nilai-nilai Pancasila tidak bertentangan dengan ajaran, keempat umat yang sekuler. Secara politis Pancasila sampai sekarang tetap efektif sebagai ideologi yang mempersatukan Indonesia namun belum efektif sebagai ideologi ekonomi, sosial, maupun budaya. Demikian itu dikarenakan Pancasila masih dipahami sebagai sebuah mitos. Bahkan selama ini Pancasila lebih disosialisasikan sebagai mitos daripada sebagai ideologi. Pancasila adalah nilai- nilai luhur bangsa yang kelahiranya jelas kapan dan dimana tanpa peduli terhadap masa lalu Indonesia yang terpecah ke dalam banyak kerajaan saling berperang berebut hegemoni. Sampai di sini kita masih percaya bahwa "Indonesia sejak dulusudah Bhineka Tunggal Ika" dikarenakan sudah ada "Sumpah Palapa”( Kuntowijoyo, 1997: 80).

Kendatipun demikian, pada kondisi kritis seperti yang terjadi pada tahun pada 1965, mitos lebih efektif daripada ideologi sebab mitos bertumpu pada 
kepercayaan sedangkan ideologi pada intelektualitas. Namun, dalam kondisi normal mitos akan lumpuh dan tidak berdaya. Mitos lebih subjektif dan irasionalmistifikatif sedangkan ideologi lebih objektif dan rasional dialektis. Dalam rangka menghadapi industrialisasi maka tidak ada jalan lain kecuali mengembalikan Pancasila sebagai ideologi. Artinya, Pancasila harus dijadikan rasional. Rasionalisasi Pancasila tidak berarti "mempersoalkan" Pancasila dalam pengertian meragukan, melainkan lebih mengefektifkannya sebagai ideologi rasional dengan mengubah cara pemasyarakatannya. Hal ini berarti bahwa alam pikiran mitis yang selama ini dipakai dalam memasyarakatkan Pancasila harus diganti dengan alam pikiran sejarah, sebagaimana yang sudah dianjurkan oleh Sudjatmoko sejak 1957, yaitu sejak Seminar Sejarah Nasional I. Dengan demikian, sebagai ideologi Pancasila dituntut untuk tetap pada jati dirinya baik ke dalam (segi intrinsik) maupun ke luar (segi ekstrinsik). Ke dalam, Pancasila harus konsisten, koheren, dan koresponden. Ke luar, Pancasila harus menjadi penyalur dan penyaring kepentingan horizontal maupun vertikal.

\section{Keterkaitan Pancasila dengan Ajaran Islam.}

Mayoritas penduduk Indoneisia adalah umat muslim oleh karena itu semakin terasa penting bila membicarakan Pancasila barkaitan dengan kehidupan umat di Indonesia. Selama ini muncul stigma bahwa terjadi pertentangan antara dasar hukum yang dipegang umat dengan Pancasila. Hal ini adalah sebuah kekeliruan atau bisa dikatakan pengliruan pihak tertentu. Pada dasarnya mayoritas muslim di Indonesia tidak pernah bertentangan atau menentang Pancasila. Sebab, para penyusun dasar negara ini pun sebagaian besar kaum muslim apalagi bila dilihat bahwa asal Pancasila adalah Piagam Jakarta. Piagam ini merupakan buah pikir cendekiawan muslim pada masa itu. Dan dapat kita lihat juga dalam pembukaan Undang-undang Dasar 1945 disebutkan di dalamnya "Atas berkat rahmat Allah Yang Maha Kuasa....”. korelasi Pancasila dengan sudah ada sejak masa awal dibentuknya. Sila-sila Pancasia merupakan bagian dari ajaran. Sebagaimana diungkapakan oleh Ibu Nuraini: 
Sila-sila Pancasila kalau dilihat dan disesuaikan dengan ajaran Islam tidak bertentangan. Sila pertama Ketuhana Yang Maha Esa ini sesuai dengan ajaran untuk mengesakan Allah yaitu ajaran Tauhid. Bahkan kalau kita lihat yang cocok dengan sila ini ya hanya, karena umat tuhan nya hanya satu yaitu Allah, sedangkan agama lain tidak. Nasrani tuhannya tiga”.

Hal tersebut juga didukung oleh Ustadz Furqan Hasbi yang mengatakan:

Sila-sila Pancasila itu sangat terkait dengan ajaran Islam baik dari sisi historisnya maupun isi sila-silanya. Piagam Jakarta yang kemudian dihapuskan tujuh kata dan diganti dengan Ketuhanan Yang Maha Esa tetap saja sesuai dengan ajaran Islam yaitu Tauhid.

Basuki Widodo juga mengungkapkan,

Yang terdapat dalam Sila-sila Pancasila ada semua dalam ajaran Islam. Sebagai mana sila pertama Ketuhana Yang Maha Esa. Sangat cocok dengan umat muslim, beriman (percaya) dan beribadah hanya kepada Allah yang Maha Esa. Harusnya pas untuk semua manusia yang mau berpikir, karena hanya Allah Yang Maha Esa yang berhak untuk diibadahi.Untuk pemeluk agama selain tidaklah pas, karena mereka tidak berkeyakinan tuhan itu satu. Jadi Indonesia berdasarkan ketuhanan, negara yang berdasar agama dan hal ini lebih baik daripada tidak beragama. Dengan nilai agama itu menjadikan hidup bernegara damai, rukun dan beradab.

Dari data di atas dapat disimpulkan bahwa sila-sila Pancasila selaras dengan ajaran. Rumusan Pancasila yang berlaku sekarang ini, tidaklah terpisah dari UUD 1645, yang kini kembali berlaku sebagai hasil Dekrit Presiden 5 Juli 1959. Karena itu, dalam memahami sila pertama, tidak boleh terlepas dari alinea ketiga pembukaan UUD 1945: "Atas berkat rahmat Allah Yang Maha Kuasa ". Jadi sila pertama menurut berbagai tokoh organisasi, bisa dikatakan sebagai penegasan konsep tauhid dalam, sebab dalam alinea ketiga jelas-jelas disebutkan nama Tuhan Yang Maha Esa yaitu Allah (Adian Husaini, 2009, 146-147). Pada sila pertama Ketuhanan Yang Maha Esa. Sila ini merupakan urutan pertama menjiwai sila-sila berikutnya sebagaimana dalam ajaran bahwa Tauhid adalah pokok inti dari agama.

Jika kita telaah lebih jauh, konsep ideologi Ketuhanan Yang Maha Esa tidak kita temukan dalam pemahaman sifat tuhan pada masa sebelum yang 
menganut pemahaman animisme-dianmisme, kemudian pada masa Hindu-Budha yang menyembah banyak dewa dan menganut konsep Tridev yaitu merupakan manifestasi dari Brahma, Wisnu, dan Siwa. Sedangkan pada agama Nasrani yang terdapat konsep Trinitas yaitu menyembah Tuhan Bapak, Putra, dan Roh Kudus. Sangatlah jelas bahwa konsep Ketuhana Yang Maha Esa ini mengadopsi dari konsep bertuhannya umat. Banyak sekali ayat-ayat Al-Qur'an yang menegaskan tentang pengesaan Allah. Seperti dalam surat Al-Ikhlas ayat 1-5

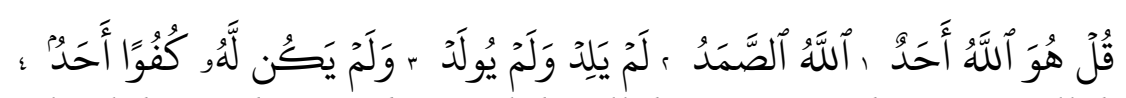

Katakanlah: "Katakanlah (Muhammad), Dialah Allah, Yang Maha Esa. Allah tempat meminta segala sesuatu. (Allah) tidak beranak dan tidak pula diperanakkan. Dan tidak ada sesuatu yang setara dengan Dia."

Lebih lanjut lagi Ibu Nuraini mengungkapkan:

Sila kedua Kemanusiaan yang adil dan beradab, ya sama dengan ajaran syariat karena dalam agama juga diajarkan untuk berbuat adil dan berakhlak mulia.

Hal ini dibenarkan oleh Saudara Yunus Prasetyo:

Iya sudah tentu pada sila kedua dalam Pancasila ini sesuai dengan apa yang diajarkan oleh, di dalam ajaran agama kita harus memanusiaakan manusia dalam arti kita harus berakhlak karimah dalam pergaulan (beradab) dan di dalam ajaran juga diajarkan untuk berbuat adil, tidak memandang kedudukan ataupun kekayaan. Semua sama dihadapan Allah, yang membedakan ya hanya ketakwaan.

Dari data di atas dapat disimpulkan bahwa umat di lingkungan masjid AlManar memahami bahwa sila kedua ini selaras dengan ajaran Islam. Ini menunjukkan bahwa adanya indikasi yang kuat bahwa pandangan dunia terdapat pada rumusan Pancasila. Sejumlah kata kunci yang maknanya sangat khas yaitu "adil" dan "'adab". Dua kata ini jelas berasal dari kosa kata, yang memiliki makna khusus (istilahan) dan hanya bisa dipahami dengan tepat (Adian Husaini, 2003: 214). Adil adalah istilah yang khas yang terdapat banyak sekali ayat Al-Qur'an, sebagai contohnya dalam surat An-Nahl ayat 90:

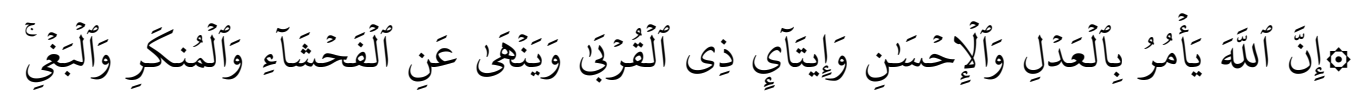

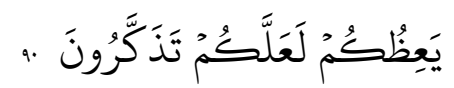


90. Sesungguhnya Allah menyuruh (kamu) berlaku adil dan berbuat kebajikan, memberi kepada kaum kerabat, dan Allah melarang dari perbuatan keji, kemungkaran dan permusuhan. Dia memberi pengajaran kepadamu agar kamu dapat mengambil pelajaran.

Istilah adab juga merupakan salah satu istilah dasar dalam. Para ulama telah banyak membahas makna $a d a b$ dalam pandangan, $a d a b$ terkait dengan iman dan ibadah dalam adab bukan sekedar "sopan santun". Menurut harkat dan martabat sesuatu adalah berdasarkan ketentuan Allah, dan bukan manusia. Sebagai contoh: orang yang mulia adalah orang yang paling takwa. Maka seharusnya, dalam masyarakat yang berdadab, kaum muslimin menghormati manusia karena keimanan dan ketakwaannya. Bukan sekedar karena jabatan atau kekayaan. Jadi orang yang beradab adalah orang yang dapat memahami dan meletakkan sesuatu pada tempatnya, sesuai dengan harkat dan martabat yang ditentukan oleh Allah (Adian Husaini, 203: 225). Sikap perilaku manusia yang adil dan beradab adalah pencerminan sifat Tuhan Yang Maha Tuhan Yang Maha Adil dan Maha Memuliakan Hamba-Nya. Ideologi yang mengutamakan penghormatan dan penghargaan atas manusia setelah mengakui keesaan Tuhan inilah penjelmaan habl min Allah dan habl min an-nnas dalam ideologi Pancasila. Selain hal itu Ibu Tri Ningsing mengungkapkan:

Sila ketiga Pancasila yaitu Persatuan Indonesia itu sama dengan ukhuwah Islamiyyah dalam ajaran Islam.

Hal tersebut juga dibenarkan oleh Ustadz Furqan Hasbi:

Berkenaan dengan sila ketiga Pancasila sangat terkait erat dengan ajaran Islam, mengajarakan persaudaraan ukhuwah Islamiyyah, persaudraan sesama muslim yang seaaqidah dan persaudraan sesama manusia.

Dapat kita lihat dari data di atas keterkaitan sila ketiga dengan ajaran Islam. Persatuan Indonesia mengandung di dalamnya, bahwa bangsa Indonesia adalah satu, tidak dapat dipecah-pecah. Persatuan Indonesia diperkuat dengan Bhineka Tunggal Ika, bersatu dalam berbagai ragam. Bangsa ini memang 
diciptakan dalam keaneka ragaman suku, ras, budaya. Seperti dalam Al-Hujurat ayat 13 Allah menciptakan manusia berbangsa-bangsa dan bersuku-suku untuk saling mengenal bukan untu saling berpecah belah. Islam juga sangat menganjurkan persatuan dapat kita lihat dalamAl-Baqarah ayat 213:

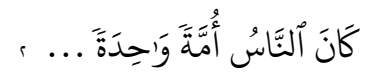

\section{Manusia itu adalah umat yang satu.}

Dan surat Ali-Imron ayat 103

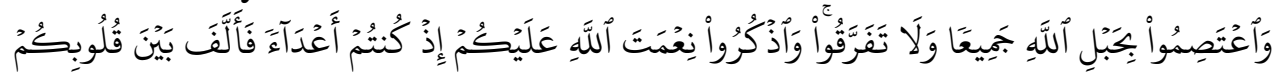

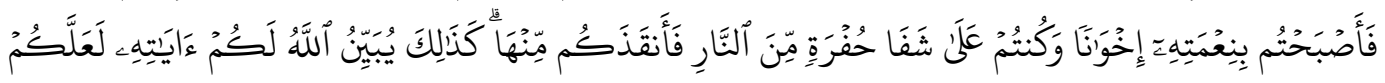

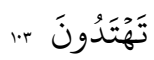

103. Dan berpeganglah kamu semuanya kepada tali (agama) Allah, dan janganlah kamu bercerai berai, dan ingatlah akan nikmat Allah kepadamuketika kamu dahulu (masa Jahiliyah) bermusuh-musuhan, maka Allah mempersatukan hatimu, lalu menjadilah kamu karena nikmat Allah, orang-orang yang bersaudara; dan kamu telah berada di tepi jurang neraka, lalu Allah menyelamatkan kamu dari padanya. Demikianlah Allah menerangkan ayat-ayat-Nya kepadamu, agar kamu mendapat petunjuk.

Kemudian dalam sila keempat kerakyatan yang dipimpin oleh hikmat kebijaksanaan dalam permusyawaratan perwakilan Ibu Nuraini mengatakan:

Iya dalam sila kelima ini juga sepadan dengan ajaran Islam, didalam agama kan juga mengajarkan untuk musyawarah dalam mengambil keputusan demi kepentingan bersama.

Hal ini juga dibenarkan oleh Yunus Prasetya:

Kalau bekaitan dengan sila keempat yaitu kerakyatan yang dipimpin oleh hikmat kebijaksanaan dalam permusyawaratan perwakilan ini sama halnya dengan ajaran Islam, didalam juga diajarkan musyawarah, di dalam mengenal yang namanya "syuro" atau musyawarah, jadi kata musyawarah ini berasal dari kata syuro.

Islam adalah agama yang mengutamakan kemaslahatan umat, dengan demikian menjadi logis bahwa mengutamakan musyawarah dan kerjasama untuk mencapai tujuan yang diharapkan. Di dalam Al-Qur'an terdapat perintah supaya bermusyawarah dalam urusan dunia seperti dalam surat Ali-Imran ayat 159:

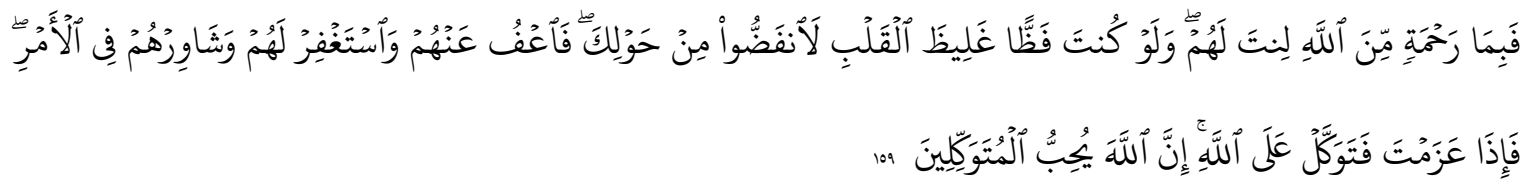


159., dan bermusyawaratlah dengan mereka dalam urusan itu.

Selanjutnya dalam sila kelima keadilan sosial bagi seluruh rakyat Indonesia, Bapak Najmudin mengatakan:

Sila kelima Keadilan sosial bagi seluruh rakyat Indonesia ya itu ada ajarannya di dalam Islam, contohnya bersedekah, zakat, dan juga berkurban, hal ini merupakan cerminan bahwa Islam sangat memeprhatikan kesejahteraan umatnya, saling berbagi antara yang kaya dan yang kurang mampu.

Hal ini dibenarkan oleh Ustadz Fuqan Hasbi:

Kalau sila kelima Pancasila ini di dalam Islam berkaitan dengan keadilan dalam pemerataan maal, yaitu di dalam Islam ada perintah untuk berzakat dan bersedekah.

Keadilan sosial berkaitan dengan pemerataan kesejahteraan bagi seluruh rakyat Indonesia. Di dalam Islam ada sebuah konsep masyarkat yang berkeadilan. Islam sebagai agama yang tidak melupakan sistem kemasyarakatan, menjunjung tinggi sistem pemerataan, perekonomian. Agama Islam menentukan bahwa harta yang dimiliki oleh setiap orang melekat padanya hak-hak fakir dan miskin. Ketentuan ini didasarkan pada firman Allah dalam surat Adz-Dzariyat ayat 19:

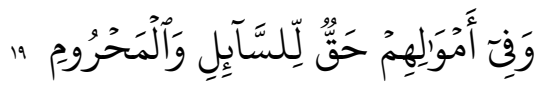

19. Dan pada harta-harta mereka ada hak untuk orang miskin yangmeminta dan orang miskin yang tidak mendapat bagian.

Prinsip sosial yang telah diamalkan oleh kaum muslim, dimana seluruh umat Islam harus merasakan kesejahteraan, intinya sama dengan sila kelima yaitu kesejahteraan sosial bagi seluruh rakyat Indonesia. Harta yang dimiliki masyarakat harus beredar secara adil dalam masyarakat itu pula. Sila-sila Pancasila merupakan bagian dari ajaran Islam. Maka dapat kita katakan bahwa sebagai ideologi Pancasila adalah objektivikasi. Hal ini berarti bahwa unsur-unsur objektif agama ada dalam Pancasila Oleh karena pertemuan dua subtansi yang berangkat dari titik yang berbeda (dari nash Al-Qur'an dan Sunnah sementara Pancasila dari realitas sosial masyarakat) harus lebih dipahami sebagai sesuatu yang berimplikasi positif daripada harus mempertentangkanya. Nilai-nilai 
universal Islam secara eksplisit menjiwai muatan Pancasila yang berprinsip ketuhanan, kemanusiaan, persatuan, permusyawaratan, dan keadilan. Hal ini sejalan Islam dengan yang menekankan persamaan, persaudaraan, permusyawaratan, keadadilan dan ketuhanan.

\section{Penanaman Nilai-Nilai Pancasila Dan Ajaran}

Pancasila sebagai dasar negara terkandung didalamnya nilai-nilai yang luhur yang merupakan cerminan dari masing-masing silanya. Secara realitas historis dan kandungan sila-sila Pancasila sangat erat hubungannya dengan ajaran Islam. Berdasarkan pembahasan di atas Pancasila adalah objektivikasi. Dalam realitanya praktek penanaman nilai-nilai Pancasila dan ajaran Islam sangatlah diperlukan. Karena sebagian besar umat Islam telah melupankan nilai-nilai Pancasila ini. Sebagaimana yang diakatan oleh Bapak Basuki Widodo:

Pada zaman modern sekarang ini di kalangan masyarakat kita nilai-nilai Pancasila sudah mulai terkikis, ya bahkan anak muda kita sudah lupa nilainilai Pancasila, tidak seperti pada zaman dahulu yang rasa kekeluargaan dan kegotongroyongan masih sangat kental sekali.

Hal ini dibenarkan dengan perktaan Saudara Yunus:

Di lingkungan kami masyarakatnya mayoritas muslim, mereka belum begitu peduli dengan nilai-nilai Pancasila, mungkin hanya hapal saja, namun dalam prakteknya nilai-nilai itu sudah terlupakan, karena masyarakat sekarang lebih sibuk dengan bagaimana bekerja mencari uang untuk hidup, tetapi dalam kehidupan masyarakat masih terlihat nilai-nilai Pancasila yang tetap terjaga seperti rasa ukhuwah, gotong royong dan musyawarah.

Dalam kegiatan masjid Al-Manar belum ada kajian khusus yang mengajarkan tentang penanaman nilai-nilai Pancasila ataupun pembelajaran Pancasila dalam sudut pandang kajian Islam. Di masjid Al-Manar hanya diadakan kajian-kajian rutin untuk masyarakat sekitar mulai dari TPA untuk anak-anak, kajian rutin bagi ibu-Ibu, bapak-bapak, dan remaja putri dan putra.

Di masjid kami tidak ada kajian khusus yang membahas tentang penanaman nilai-nilai Pancasila, yang kami ajarkan ya syariat.

Hal ini dibenarkan oleh Ibu Nuraini: 
Di lingkungan masjid ini diadakan kajian rutin untuk ibu-ibu, bapak- bapak, anak-anak dan remaja, tetapi ya yang diajarkan ya tentang syariat Islam, bukan tentang nilai-nilai Pancasila, namun dengan diajarkannya syariat Islam secara tidak langsung hal ini juga termasuk penanaman nilai- nilai Pancasila karena sila-sila Pancasila kandunganya sama dengan ajaran Islam. Kami diajarkan pelajaran tauhid yaitu mengesakan Allah, diajarkan juga bermualmalah dengan baik dalam masyarakat.

Ustadz Fuqan Habsi Juga mengatakan:

Selama ini belum ada kajian khusus yang membahas tentang penanaman nilai-nilai Pancasila secara langsung, kami hanya menyampaikan syariat Islam (nilai-nilai ajaran Islam), tetapi secara tidak langsung nilai-nilai Pancasila juga telah disampaikan dan kami pun secara tidak sadar telah melaksankan nilai-nilai Pancasila, seperti menyembah hanya kepada Allah, bersedekah dan berzakat, kami juga melakukan musyawarah. Hal- hal ini termasuk juga nilai-nilai Pancasila hanya saja kami tidak menyadarinya, karena kami mengangapnya ya menjalankan syariat Islam.

Hal ini didukung dengan perkataan Anjmudin Zuhdi:

Selama umat itu menajalankan syariat Islam dengan benar, ya secara tidak disadari dia telah menjalakan juga nilai-nilai Pancasila, Alhamdulillah di lingkungan masjid kami tidak ada tawuran, masyarakatnya hidup rukun, kalau dilihat dari esensi sila pertama kami sudah mengajarkan tentang tauhid kepada masyarakat, kemudian tentang sila yang kedua yaitu kami mengajarkan untu berkahlak baik dalam masyarakat, kemudian yang berkaitan dengan sila ketiga yang kami ajarkan ya ukhuwah islamiyyah dan rasa persaudaraan sesama warga masyarakat, kemudian berkenaan dengan sila keempat hal ini kami terapkan dalam mengambil keputusan bersama warga ataupun pengurus masjid dengan jalan musaywarah, kemudian klau berkenaan dengan sila ke lima, ya Alhamdulillah setiap tahun sudah bisa berkurban, kami mengajarkan sedekah dan zakat, setiap pengajian itu semua snack dari warga, saling membantu untuk menjalankan kajian rutin.

Menanamkan nilai-nilai Pancasila dalam perpektif ajaran Islam adalah penting. Karena yang hadir di Indonesia adalah yang mampu berdialektika dengan realitas sosial masyarakatnya setempat, dan tidak lagi saklek, dalam menterjemahkan Al-Qur'an dan Sunnah. Nilai-nilai Pancasila adalah bagian dari nilai-nilai ajaran Islam. Sebagai umat dengan menjalankan syariat Islam dengan baik secara tidak disadari telah juga menjalankan niali-nilai Pancasila. 


\section{Kesimpulan}

Berdasarkan pemaparan dan pembahasan dari bab-bab sebelumnya, maka dapat diambil kesimpulan: pertama, mayoritas masyarakat di lingkungan masjid AlManar memahami arti dan fungsi Pancasila sebagai dasar negara dan pemersatu bangsa Indonesia. Kedua, pola pemahaman sebagian masyarakat muslim di lingkungan masjid Al-Manar memahami Pancasila sebagai ideologi tersendiri, dan ajaran Islam sebagai ideologi tersendiri, meskipun esensi nilai- nilai Pancasila tidak menyelisihi dari ajaran agama Islam, dan pancasila sebagai simbol dasar negara saja. Sebagian yang lain berpendapat bahwa nilai-nilai Pancasila termasuk bagian dari nilai ajaran Islamdan di masjid Al-Manar belum ada kajian yang membahas mengenai Pancasila secara khusus, namun sudah ada beberapa kajian rutin yang secara tidak langsung mengandung nilai-nilai Pancasila, seperti tauhid yang terkandung dalam sila pertama Pancasila dan sila- sila lainnya. 


\section{Daftar Pustaka}

Fuad, foky. 2012. dan Ideologi Pancasila, Sebuah Dialektika. Jakarta: UAI.

Husaini, Adian.2009. Pancasila bukan Untuk Menindas Hak Konstitusi Umat . Jakarta: Gema Insani.

Kansil. 2005. Pancasila dan Undang-undang Dasar 1945. Jakarta: Padya Paramita.

Karim, Abdul. 2004. Menggali Muatan Pancasila dalam Perspektif. Yogyakarta: Surya Raya.

Kuntowijoyo. 2004. Isalm sebagai Ilmu: Epistemologi, Metodologi, dan Etika. Jakarta: Teraju. 1997. Identitas Politik Umat . Bandung: Mizan.

Miller Mathew B, Habermean Michael. 1992. Analisis Data Kualitatif. Jakrta: UI Press.

Moleong, Lexy. 2007. Metodologi Penelitian Kualitatif. Bandung: Remaja Rosda Karya.

Nasution. 2006. Metode Research. Jakarta: Bumi Aksara.

Sukmadinata. 2010. MetodePenelitian. Bandung: PT. RemajaRosdakarya.

Surip, Ngadino. 2015. Pancasila dalam Makna dan Aktualisasi. Yogyakarta: Andi.

Sutopo. 2002. Metode Penelitian Kualitatif. Surakata: UNS Pers.

Ubaedillah, A. 2015. Pancasila Demokrasi dan Pencegahan Korupsi. Jakarta: Prenada Media Group.

Yamin, Muhammad. tt. Pembahasan Undang-Undang Dasar Republik Indonesia. Jakarta: Prapanca.

http://id.m.wikipedia.org/wiki/wawancara diakses tanggal 23 desember 2016 jam $08.00 \mathrm{WIB}$.

http://kbbi.web.id/hidup diakses pada tanggal 24 Desember 2016 pukul 16.07 WIB. 